many as 420 people are to be found crowded within the limits of one square kilometre. The total debt of the Government is reckoned at 266,000 , 000 francs, of which $214,000,000$ francs have been contracted within the Empire itself, leaving only $52,000,000$ francs of foreign debt. The army is composed of two large bodies : the Tartar army, including the Manchoos and the Mongols; and second, the Chinese army. The Tartar army, guarding Pekin, the frontiers, and the coast, comprises the army of Manchooria of 30,000 men, the Mongolian army of 20,000 men, the Turkestan army of 4.0,000, and lastly the army occupying the maritime provinces, numbering 100,000. The Chinese army proper is distributed throughout the eighteen provinces, and performs the functions of police in addition to its military duties. Its number ranges from 20,000 to 100,000 in each province, according to its population and its defensive requirements. The navy in 1879 was estimated to comprise fifty-six ships armed with 283 guns, and manned by 5860 marines. Since that date, however, the fleet has been largely developed.

L'Exploration states that the Geographical Society of Amsterdam is about to acquire the fac-simile of the most ancient map known, and which represents the Roman Empire as it was in the time of Augustus. It is formed of eleven folding maps, which make one large map $8 \frac{1}{2}$ metres in length. The original is in the Royal Library at Vienna, which purchased it in the sixteenth century from the estate of Conrad Peutinger of Augsburg, a circumstance which gave the map its name of Tabula Peutingeriana. Peutinger purchased it for 40 ducats. The original, which is dated I 265, was the work of a Dominican monk of Colmar.

THE deaths are announced of two Italian geographers and travellers, Eugenio Balbi and Carlo Guarmani. The former was the son of the celebrated Adrien Balbi, and was born at Florence in 1812. After several years' travel in Europe, he finally returned to Italy, where he devoted all his energy to the study of ethnography and gengraphical science. His principal works are: "Gea"; "I monumenti della geografia nell' evo medio e moderno"; "L'Italia nei suoi naturali confini." Guarmani had travelled wiciely, and in his last years was one of the correspondents of the geographical review of Milan, L'Esploratore.

THE Institute of Argentine Geography has decided to organise an expedition into the Andes of Patagonia. The explorers will leave Lake Nahuel-Huapi, and uil then undertake a detailed investigation from a geographical point of view of the Argentine slope of the Andes, following it to the Straits of Magellan. The head of the expedition will be Capt. Moyano, who has been instructed to present a report to the Institute at the earliest possible date, indicating the plan of work, the instruments, and other objects necessary, as well as an approximate estimate of the expense. The Federal Government will be requested to grant the co-operation of the troops stationed on the frontiers of Limay, as well as to send a sloop-of-war to act where possible in concert with the expedition.

\section{A TEACHING UNIVERSITY FOR LONDON}

IN connection with our leading article this week we append the following Plan for Promoting a Teaching University for London, which was discussed at the meeting :-

A sub-committee was appointed on Monday, November Io, to draw up a plan, in accordiance with the objects of the Association for promoting a Teaching Univer-ity which are as follows:-(I) The organisation of University Teaching in and for London, in the form of a Teaching University, with Faculties of Arts, Science, Medicine, and Laws. (2) The association of University Examination with University Teaching, and direction of both by the same authorities. (3) The conferring of a substantive voice in the government of the University upon those engaged in the work of University Teaching and Examination. (4) Existing Institutions in London, of University rank, not to be abolished or ignored, but to be talsen as the bases or component parts of the University, and cither partially or completely incorporated, with the minimum of internal change. (5) An alliance to be established between the University and the Professional Corporations, the Council of Legal Education as representing the Inns of Court, and the Royal Colleges of Physicians and of Surgeons of Londion.

The Sub-Committee, consisting of Lord Reay, Chairman, Prof. Tohn Marshall, F.R.S., Ex-P.R.C.S., Dr. W. M. Ord,
F.R.C.P., Mr. F. Pollock, Barrister-at-Law, Mr. R. S. Poole, British Museum, Dr. P. H. Pye Smith, F. R.C.P., Prof. G. C.W. Warr, King's College, Prof. A. W. Williamson, University College, and Sir George Young, met and considered the subject of reference, and submitted the following proposed plan of a Teaching University for London for the consideration of the Committee, on Monday, the $15^{\text {th }}$ inst. :-

(a) Tine Constitution of the Teaching University. - To be founded on (I) the Faculties or Constituent Bodies (2) a Board of Studies for each Faculty ; (3) a Governing Body or Council.

(r) The Council.-To consist of Members representative of -

(a) The several Faculties. The proportion of representatives of the Faculties to the whole number of the Council to be at least one-third.

(b) The Senate of the University of London.

(c) The Council of Legal Education.

(d) The Royal Colleges of Physicians and of Surgeons.

(e) It should be a point for future consideration whether other Public Bodies should be directly represented on the Council, e.g., the Anthorities of the British Museum, of the Royal Academy and Royal Society, of the Incorporated Law Society, and of the Institute of Civil Engineers.

(f) Colleges and other Educational Institutions associated with the University. The amount of representation and the qualification for direct representation on the Council to be determined, in each case, having regard both to the nature and the amount of the educational work performed by the Associated Institution.

(g) Endowing Bodies, e.g., the Crown, if the Teaching University should receive State endowment ; the Corporation and Companies of the City of London, if they contribute to endow the University.

Representatives of Associated Institutions and Endowing Bodies not to exceed one-third of the whole number of places on the Council.

(2) The Boards of Studies, - To be elected by each Faculty. Some additional Members might be appointed by the Council. The Board to advise in all matters relating to the Faculty, and to exercise authority in such matters as are delegated to it by the Council. Facilities to be provided for joint meetings and action of two or more Boards of Studies when necessary. The Board to appoint some or all of the representatives of the Faculty upon the Council. If any are appointed by the Faculty direct, they should also be ex officio Members of the Board.

(3) The Faculties.-To consist for electing purposes of -

(a) Teachers : being Professors, Lecturers, or persons of equivalent standing, in the Colleges or Educational Institutions associated with the University.

(b) Examiners for the time being in the Teaching University and in the existing University.

(c) Additional Members, to be appointed by the Council, on the recommendation of the Board of Studies.

There might also be Honorary Members of Faculties, including Graduates in that Faculty, of the Teaching University; Members of Convocation of the existing University according to their Degrees; recipients of degrees honoris causî, and so forth; such IIonorary Members having the right to attend and vote only at a General Meeting of the Faculty, to be summoned on requisition when necessary.

(b) RELATIONS OF THE TEACHING UNIVERSITY WITH OTHER Bontrs. --(I) The Ex isting University. - There might be one Chancellor, with two Vice-Chancellors, the Teaching University and existing University constituting one University in two departments. The Degrees might, if necessary, be distinguished by their designation in some suitable manner. The Senate of the existing University would remain unaltered, would be appointed as at present, and would control the present Examinations and confer Degrees, without interference. Convocation might accept the Graduates of the Teaching University as fill Members. The Teaching University might, so far as is practicable, find a place of meeting at Burlington House, together with the existing University.

(2) The Professional Corporations.-Degrees in Law, Medicine, and Surgery to be recognised as qualifyiug pro tanto for Call to the Bar or for Licence to practise, the power of Calling to the Bar or of conferring Licences to praclise being reserved to the existing Authorities. The previous Examinations of the Teaching University to receive recognition by those Authorities. such as is now given to the Examinations of existing Universities. 
(3) Colleges, Educational Institutions, Special Schools, and Institutions for Purposes of Research.-Each Associated Institution to remain unaffected in any way, save in so far as it might be willing to adopt the recommendations of the University Council.

The School of Law of the four Inns of Court to be an Associated Institution, and its Professors and Examiners to be Members of the Faculty of Law, but without further direct representation on the Council than that already given to the Council of Legal Education.

The recognised Hospital Schools of London to be Associated Institutions, and their Professors and Lecturers to be Members of the Faculty of Medicine.

The direct representation of the Hospital Schools on the Council being difficult, owing to their number, it might be provided that they should all have one representative, at least, on the Board of Studies of the Medical Faculty.

Schools of Fine Art and Technical Schools employing Teachers, some of whom are not engaged in what can be called, strictly speaking, University work, if composing part of an Associated Institution, to be admissible as Special Schools of the University, and their principal Teachers to be Members of the appropriate Faculties.

Junior Schools forming part of Associated Institutions to be admissible similarly as Special Normal Schools, for the purpose of training Teachers.

Institutions for purposes of Research to be admissible as Special Schools, and their Principals or principal Members to be eligible as additional Members of the appropriate Faculty.

Educational Institutions, of which the work is either in kind or quantity insufficient to entitle them to rank as Associated Institutions, while at the same time partaking of a University character, to be similarly admissible as Special Schools.

(c) WORK OF THE TEaching UNIVERSITY. - The Teaching University to obtain power to confer the usual Degrees, either by way of supplemental Charter to the University of London or otherwise, after such course of study and examination as may be determined on.

As means and opportunity will allow, the Teaching University to appoint Professors in the more advanced studies, and for purposes of original research.

The Council to negotiate with Associated Institutions for the increase of facilities for common attendance at lectures, laboratory work, and admission to Libraries and Museums, and for the concentration of teaching within one or more of such Institutions, or within the University itself, in such studies as may appear desirable.

The extent to which it may be found possible to blend the examinations of the Teaching University with those of the existing University, of the Professional Corporations, or of other Examining Bodies, to be determined hereafter, full liberty of action being reserved to the respective Authorities.

Professors, Lecturers, \&c., who are Members of the Faculty, to have the title of " — Professor, Lecturer, \&c., of (or on) -_ " in the proposed University; the first blank denoting ceded by the title (if any) by which their Chair or other office is known.

Students in Associated Institutions and Special Schools to be at liberty to become Undergraduates in the T'caching University, or to obtain Degrees as at present from the existing University. Signed on behalf of the Sub-Committee,

$$
\text { REAY, Chairman }
$$

\section{NATURE-DRAWING 1}

\section{$\mathrm{B}^{\mathrm{E}}$}

EFORE explaining the objects aimed at in the new drawing classes proposed to be formed in University College School, to be called Nature-Drawing Classes, let us look back and note briefly what we have achieved up to the present time, and gather if wc can from it what kind of foundation we have for the work we are about to do, and what our necessities are in order to secure success. Of the past I am able to speak with some authority, having been connected with the drawing classes in this school for nearly forty years. That we have achieved a very considerable success is proved by the high position thes= classes are known to hold as compared with similar classes in other public schools; also by the fact that every boy who has

'An address by W. H. Fisk, in part delivered at University College
School, Gower Street, taken the "Trevelyan Goodall Art Scholarship" in the school and has competed for the Slade Scholarships in the Slade Schools of Fine Art in University College has, without an exception, succeeded in securing the object of his ambition, and in the case where two of our boys were competitors at the same time, they succeeded in carrying off both scholarships, and all in competition with students older than themselves.

Now it is evident that such remarkable success must rest on some very sound foundation. Though there is no doubt that our method of teaching may account in part for this, and in no small part, yet by far the larger part of the foundation of this success has been laid by the zeal, energy, and intelligence in teaching displayed by the assistant drawing-masters, and I desire frankly, and without any reservation whatever, not only to acknowledge their signal ability and their right to the merit due from the results, but also to acknowledge my own indebtedness to their loyalty in giving effect and unity to the method of teaching, without which our success could never have been secured. The teaching has hitherto ranged from the drawing of simple geometrical forms to the drawing of the figure from the antique, together with mechanical drawing, model drawing, and perspective. And now I have a word for the younger boys, who, sometimes, may find the repeated drawing of curved and other lines a little wearisome, but they may rest assured that they are doing valuable work, and acquiring an invaluable power, for it is mainly in the combination of these curved lines, in the perception of their grace, and the power to render them accurately and freely, that the expression of the most beautiful $\mathrm{f} \mathrm{rm}$, and even the recognition of it, at length becomes possible.

That curriculum in our public schools is best which has the greatcst elasticity, and is not bound so closely within the four walls of precedent that it is deprived of the power to expand in any direction to meet the necessities of the times. That the teaching of drawing in our public schools has not advanced adequately to meet these necessities will be, in most cases, frankly recognised by the teachers themselves. But the fault does not lie at their door. It is the "governing bodies" of our public schools, and the outside public, who are to blame. The past low estimate of both alike as to the utility of drawing as a serious study has proved the detriment to its advance. Both have recognised in drawing little more than a sort of harmless amusement to keep children out of mischief when not otherwist employed. Both have been blind to the influence which the imitation of beautiful forms must needs have on the minds of the young, and, yet more, to the influence it must have in after life. A love for beautiful form goes far towards making a beautiful life. While due effect is given to the utilitarian side of education, the rsthetic side cannot be ignored, but through literature and art the resthetic phase of the student's mind should be developed as widely as possible, and, as a help to this, Prof. Huxley has publicly stated his conviction that it should be made absolutely necessary for everybody for a longer or a shorter period to learn to draw, and that there is nobody who cannot be made to draw more or less well.

It is proposed to arrange the new nature-drawing classes under two broad divisions, namely, landscape-art and science-art. Let us deal first with the proposed study of landscape-art, and, in order to make the direction these studies are to take the more clear, it were as wcll to state the direction they are not to take. They are not to take their direction on the old lines of making, in a blind, ignorant way, copies from the flat to be "finished off" by the more or less facile pencil of the master, and sent home as the work of the pupil at the close of the term. The influence of such palpable dishonesty can only be bad, and the more bad because of the openness with which the fraud is committed. It may be asserted that no fraud is intended, but is not almost every child sensible that there is a very real fraud, to which he has been made a party without his consent, when he shows his drawings and is praised for work he is well aware is not his own? Moreover, do you think he does not recognise how frequently and casily the fraud succeeds? But enough; le1 us dismiss it - it is bad. In the "nature-drawing" classes in University College School, landscape-drawing from the flat will be used only to secure with the pencil and the brush that technique absolutely needful. Concurrently, lessons will be given in the shape of lectures on natural phenomena, towards inducing a close, intelligent observation of them, in the belief that a boy will not draw an object - a cloud or a tree from Nature - any the worse, or with any the less interest, because he knows something about it, some scientific facts concerning it. Drawing is a record 